International Research Journal of Management, IT \& Social Sciences
Available online at https://sloap.org/journals/index.php/irjmis/
Vol. 8 No. 1, January 2021, pages: 25-34
$\begin{aligned} & \text { ISSN: 2395-7492 } \\ & \text { https://doi.org/10.21744/irjmis.v8n 1.1101 }\end{aligned}$

\title{
The Role of Organizational Commitments in Mediating the Effect of Work Motivation and Job Satisfaction towards Turnover Intention on Nurses Private Hospital
}

Article history:

Submitted: 27 October 2020

Revised: 09 November 2020

Accepted: 18 December 2020

\section{Keywords:}

job satisfaction;

nurses;

organizational commitment;

turnover intention;

work motivation;

\begin{abstract}
This study aims to determine the role of organizational commitment in mediating the effect of work motivation and job satisfaction on turnover intention of nurses at private hospitals in South Kuta. The number of samples used was 82 nurses using saturated sampling technique or census methods and collecting data using a questionnaire that uses a Likert scale. The data analysis technique was performed using Structural Equation Modeling (SEM) with the Partial Least Square (PLS) approach, and the VAF test to test the role of mediation. The results show that there is a negative and significant influence of organizational commitment, work motivation, and job satisfaction on turnover intention. There is a positive and significant effect of job satisfaction and work motivation on organizational commitment, as well as the role of organizational commitment as a partial mediator between work motivation and job satisfaction on turnover intention which has a negative and significant effect. The findings in this study imply that companies are required to pay more attention to appropriate compensation and to reward employees who are loyal to the company and pay attention to the working conditions of their employees so that employees will remain in the company.
\end{abstract}

International research journal of management, IT and social sciences (C) 2021. This is an open access article under the CC BY-NC-ND license (https://creativecommons.org/licenses/by-nc-nd/4.0/).

\section{Corresponding author:}

Made Widya Astiti,

Economics and Business Faculty,

Udayana University, Denpasar, Indonesia.

Email address: made.widyastiti@gmail.com

\footnotetext{
Economics and Business Faculty, Udayana University, Denpasar, Indonesia
}

Economics and Business Faculty, Udayana University, Denpasar, Indonesia 


\section{Introduction}

Human resources (HR) are one of the factors that determine the success of an organization. HR management is crucial for a company, as well as an HR management in hospitals, one of which is the nursing workforce which is seen as an essential asset for companies engaged in the health sector. Reflecting on this, good nursing staff management must support services in the hospital. However, hospitals often experience the turnover of employees, especially nurses, and it becomes a problem because it has an impact on hospital losses (Ridlo, 2012). The phenomenon of the entry and exit of nurses at the hospital is called turnover, which can be interpreted as moving employees from one job to another for a specific reason. The employee turnover rate in health services takes 23 percent of all employees, and 50 percent of them are nurses. Turnover can be in the form of resignation, transfer outside the organizational unit, dismissal, or death of an organization member. If a hospital has a high nurse turnover rate, this is an indication of decreased motivation and morale for its nursing staff. According to Nerissa (2015), employees who choose to leave the organization where they work can be triggered by their desire to get a better job, which makes them prefer to leave their jobs.

Based on the results of the interview, it was found that some nurses had the desire to leave their place of work because they were not satisfied with the compensation provided by the hospital and the work system that kept changing added to the workload. According to research from Li et al. (2018), states that employee dissatisfaction at work can make employees have the desire to leave.

The turnover process is usually marked by the emergence of a condition where employees have a desire to leave the company, which is called turnover intention (Widjaja, 2006). According to Basariya \& Ahmed (2019), the turnover intention is the condition of an employee in an organization who has plans to leave work, or an organization's condition has a plan to terminate work relations with employees. The problem of discharging nursing staff from the hospital can also encourage other nursing staff to have a desire to quit (Mobley, 2011). Turnover intention to employees can be characterized by various behaviors such as high absenteeism, decreased performance, breaking the rules, and the presence of courage to oppose superiors (Harnoto, 2002). The factors that can affect turnover intention to nurses are work motivation, job satisfaction, and commitment (Martoyo, 2000; Mosadeghrad, 2013).

Work motivation is defined as the willingness of employees to exert a high level of effort towards organizational goals conditioned by efforts to meet some of their individual needs (Ramlall, 2004). Work motivation plays a role in increasing the productivity of employee performance so that it has an impact on the achievement of company goals. If the work motivation of nurses is low, it will undoubtedly have an impact on hospital performance, and the goals of nurses cannot be fulfilled so this can trigger a desire to be discharged from the hospital (Wardana et al., 2020). According to research by Wang et al. (2019) and Kim (2018), which state that the higher the employee's work motivation, the lower the turnover intention.

Job satisfaction is an assessment, feelings, or attitudes of employees towards their work related to the work environment, type of work, compensation, relationships between coworkers, social relations in their workplace (Koesmono, 2005; Sy, 2006). Nurses can be said to have job satisfaction if their wants and needs can be met through work. If a nurse is satisfied with their job, they will feel comfortable. They will not have the desire to leave the hospital to research by Youcef et al. (2016) and Li et al. (2018), which states that the higher the level of employee satisfaction with the job, the lower the employee's desire to move or stop working.

The low level of work motivation and job satisfaction of nurses does not always affect turnover intention, based on research from Widiawati et al. (2017), which states that work motivation has a positive and significant effect on turnover intention. That is, high work motivation can also affect the nurse's intention to leave. Supported by the results of interviews with several nurses that they have high work motivation and are quite satisfied with their work but they still have the desire to leave if a government institution opens job vacancies and has the opportunity to work there. From these results, it can be said that the nurse's commitment to the company has a vital role in deciding whether a nurse will continue her career or choose to leave the hospital. By research by Fernet et al. (2017) and Youcef et al., (2016), who get the results that organizational commitment can support the effect of work motivation and employee job satisfaction on turnover intention.

Organizational commitment is a strength of the relationship that employees feel towards the organization in which they work. Organizational commitment is known to have an important influence on employee turnover intention. If nurses have a high commitment to their place of work, they will be willing to continue working in the hospital (Lam \& Gurland, 2008; Lu et al., 2002), of course, this will have an impact on the turnover rate in the company. By research by Imran et al. (2017), stated that organizational commitment influences employee turnover intention.

The level of employee commitment to the organization can also be influenced by work motivation and job satisfaction. Based on research from Nawawi (2015), which states that work motivation can affect organizational 
commitment and Mathieu et al. (2016), revealed that job satisfaction influences organizational commitment so that it means that higher work motivation and job satisfaction, the higher employee commitment to the organization. If nurses have a high organizational commitment, then indirectly, they can also reduce turnover intention. Based on the results of research by Youcef et al. (2016), stated that organizational commitment could function as a mediator between job satisfaction and turnover intention variables (Schwepker, 2001). According to Fernet et al. (2017), commitment as a mediator can have an influence on work motivation on turnover intention.

Based on the background and previous research, the hypothesis in this study is

H1: There is a negative and significant influence between work motivation and turnover intention

$\mathrm{H} 2$ : There is a negative and significant influence between job satisfaction and turnover intention

H3: Organizational commitment has a negative and significant effect on turnover intention.

H4: There is a positive and significant influence between work motivation and organizational commitment

H5: There is a positive and significant influence between job satisfaction and organizational commitment

H6: Organizational commitment mediates the effect of work motivation on turnover intention.

H7: Organizational commitment mediates the effect of job satisfaction on turnover intention.

\section{Materials and Methods}

This research uses quantitative data type and is in the form of associative causality research. The location of the research was conducted at a private hospital located in the district of South Kuta, Bali. The research was conducted at two private hospitals located in the area of South Kuta, namely the Kasih Ibu Hospital Kedonganan. This location was chosen because it found problems related to the turnover intention of nursing staff. Respondents in each private hospital in South Kuta, namely by dividing as many as 39 participants at the Kasih Ibu Hospital Kedonganan and 55 participants at the Bali Jimbaran General Hospital, with a total of 94 participants. The data analysis method used is descriptive statistics and inferential statistics.

\section{Results and Discussions}

Hypothesis testing is done by t-test by sorting for testing the direct effect and indirect effect or testing the mediating variables. The following sections describe the results of the direct effect test and the mediating variable test, respectively.

Table 1

T-Statistics

\begin{tabular}{lccc}
\hline Variable & T-Statistic & T-Table & Info. \\
\hline Work Motivation $\rightarrow$ Organizational Commitment & 2,141 & 1,9 & Significant \\
Job satisfaction $\rightarrow$ Organizational Commitment & 5,727 & 1,9 & Significant \\
Work Motivation $\rightarrow$ Turnover Intention & 2,490 & 1,9 & Significant \\
Job satisfaction $\rightarrow$ Turnover Intention & 2,097 & 1,9 & Significant \\
Organizational Commitment $\rightarrow$ Turnover Intention & 3,776 & 1,9 & Significant \\
\hline
\end{tabular}

Source: Data Processed Results, 2020

Title Astiti, M. W., \& Surya, I. B. K. (2020). The role of organizational commitments in mediating the effect of work motivation and job satisfaction towards turnover intention on nurses private hospital. International Research Journal of Management, IT and Social Sciences, 8(1), 25-34. https://doi.org/10.21744/irjmis.v8n1.1101 
Table 2

Path coefficients

\begin{tabular}{lcccc}
\hline Variable & Path coefficients & T-Statistics & P-Values & Info. \\
\hline Work Motivation $\rightarrow$ Organizational Commitment & 0,209 & 2,141 & 0,033 & Significant \\
Job satisfaction $\rightarrow$ Organizational Commitment & 0,578 & 5,727 & 0,000 & Significant \\
Work Motivation $\rightarrow$ Turnover Intention & $-0,387$ & 2,490 & 0,013 & Significant \\
Job satisfaction $\rightarrow$ Turnover Intention & $-0,370$ & 2,097 & 0,037 & Significant \\
Organizational Commitment $\rightarrow$ Turnover Intention & $-0,503$ & 3,776 & 0,000 & Significant \\
\hline
\end{tabular}

Source: Data Processed Results, 2020

Table 3

Recapitulation of test results for mediation variables

\begin{tabular}{cccccc}
\hline \multirow{2}{*}{ Mediation Variables } & \multicolumn{4}{c}{ Effect } & \multirow{2}{*}{ Information } \\
\cline { 2 - 5 } & $(\mathrm{A})$ & $(\mathrm{B})$ & $(\mathrm{C})$ & $(\mathrm{D})$ & \\
\hline Work Motivation $(\mathrm{X} 1) \rightarrow$ Organizational Commitment & $-0,105$ & -0.387 & 0,209 & $-0,503$ & Partial \\
$(\mathrm{Y} 1) \rightarrow$ Turnover intention (Y2) & $($ Sig.) & $($ Sig.) & (Sig.) & (Sig.) & Mediation \\
Job satisfaction $(\mathrm{X} 2) \rightarrow$ Organizational Commitment & $-0,291$ & $-0,370$ & 0,578 & $-0,503$ & Partial \\
$($ Y1 $\rightarrow$ Turnover intention $(Y 2)$ & (Sig.) & (Sig.) & (Sig.) & (Sig.) & Mediation \\
\hline
\end{tabular}

Source: Data Processed Results, 2020

Information : significance (Sig.) $=\mathrm{t}$-statistic $>1,96$ on $\mathrm{a}=5 \%$

(A): the indirect effect of the independent variable on the dependent variable

(B): the direct effect of the independent variable on the dependent variable

(C): direct effect of independent variables on the mediating variable

(D): the direct effect of the mediating variable on the dependent variable

\section{The effect of work motivation on turnover intention}

The results of the analysis show that work motivation has a negative and significant effect on turnover intention. The higher the level of work motivation for nurses at the South Kuta private hospital, the lower the turnover intention. These results indicate that the values contained in work motivation are well perceived and have a significant impact on the turnover intention of nurses at private hospitals in South Kuta. Work motivation is measured based on the dimensions of integrated regulation, identified regulation, introjected regulation, external regulation of turnover intention so that it will be able to make a significant contribution to increasing turnover intention to nurses at private hospitals in South Kuta. This study supports the results of previous research by Mustafa \& Ali (2019), that motivation has a negative relationship with turnover intention. Setyo (2016), which states that work motivation has a negative and significant effect on the desire to leave. According to Wang et al. (2019), motivation has a negative relationship with turnover intention. Research by Kim (2018), states that work motivation negatively and significantly affects turnover intention. According to Bonenberger et al. (2014), that the dimension of work motivation has a significant relationship with turnover intention.

\section{The effect of job satisfaction on turnover intention}

The analysis shows that job satisfaction has a negative and significant effect on turnover intention. This means that the higher the level of job satisfaction for nurses at private hospitals in South Kuta, the lower the turnover intention. These results indicate that the values contained in job satisfaction are well perceived and have a significant impact on the turnover intention rate of nurses at private hospitals in South Kuta. Job satisfaction is measured based on the dimensions of salary, job conditions, organizational policies, supervision, and interpersonal relationships to turnover intention so that it will be able to make a significant contribution to increasing turnover intention of nurses at private hospitals in South Kuta. This study supports the results of previous studies by Youcef et al. (2016) job satisfaction has a negative and significant effect on the intention to leave. According to Han et al. (2016); Liu \& Lo (2018); Li et al. (2018), job satisfaction has a negative and significant relationship to turnover intention. Pawesti \& Wikansari (2016), 
state that job satisfaction has a significant and negative effect on employee turnover intention. The research of Ananto et al. (2016), stated that job satisfaction has a negative and significant effect on the desire to leave. The results of Indrayanti \& Riana (2016), research shows that job satisfaction has a negative and significant effect on turnover intention. According to Widyadmono (2015), job satisfaction has a negative and significant effect on turnover intention.

\section{The effect of organizational commitment on turnover intention}

The results of the analysis show that organizational commitment has a negative and significant effect on turnover intention. This means that the higher the level of organizational commitment to nurses at the South Kuta private hospital, the lower the turnover intention. These results indicate that the values contained in organizational commitment can be well perceived and have a significant impact on the turnover intention rate of nurses at private hospitals in South Kuta. Organizational commitment is measured based on the dimensions of affective commitment, ongoing commitment, and normative commitment to turnover intention so that it will be able to make a significant contribution to increasing turnover intention for nurses at private hospitals in South Kuta. This study supports the results of previous studies by Park \& Jung (2015), which stated that organizational commitment could act as a mediator that affects turnover intention. Al-Emran \& Salloum (2017), Commitment hurts turnover. Organizational commitment is known to have an important influence on employee turnover intention. Kim et al. (2016), organizational commitment can mediate towards turnover intention. Imran et al. (2017), found that organizational commitment has a significant influence on employee turnover intention. Tharikh et al. (2016), found that organizational commitment has a significant effect on nurses' intention to leave and commitment as a partial mediator. Wahyuni (2015), an internal factor that affects turnover intention is commitment. According to Paat et al. (2017), there is a negative and significant influence on the Organizational Commitment variable on employee Turnover Intention.

\section{The effect of work motivation on organizational commitment}

The results of the analysis show that work motivation has a positive and significant effect on organizational commitment. The higher the level of work motivation for nurses at the private hospital in South Kuta, the higher the organizational commitment. These results indicate that the values contained in work motivation are well perceived and can make a significant contribution to the level of organizational commitment to nurses at private hospitals in South Kuta. The study supports the results of previous studies by Imran et al. (2017), who stated that work motivation positively affects organizational commitment. A study conducted by Salleh et al. (2016), also revealed a positive relationship between work motivation and organizational commitment. According to Makary et al. (2006), shows that work motivation has a positive and significant effect on employee organizational commitment. Research by Puspasari (2013), also concluded that work motivation has a positive and significant effect on organizational commitment. Arshadi's (2010), research states that work motivation and job satisfaction have a positive and significant effect on employee organizational commitment. Takase (2010), states that work motivation has a positive and significant effect on organizational commitment. According to Can \& Yasri (2016), it is concluded that motivation has a significant and positive impact on organizational commitment.

\section{The effect of job satisfaction with organizational commitment}

The results of the analysis show that job satisfaction has a positive and significant effect on organizational commitment. This means that the higher the level of job satisfaction of the nurses at the private hospital in South Kuta, the higher the organizational commitment. These results indicate that the values contained in job satisfaction are well perceived and can make a significant contribution to the level of organizational commitment to nurses at private hospitals in South Kuta. This study supports the results of previous studies by Ismail \& Razak (2016), who argue that when employees are satisfied with intrinsic satisfaction and extrinsic satisfaction from their job conditions, it can lead to more significant organizational commitment in the organization. Mathieu et al. (2016), revealed that job satisfaction has a positive influence on organizational commitment. Research by Ahn et al. (2015), stated that there was a statistically significant correlation between job satisfaction and organizational commitment. Raziq \& Maulabakhsh (2015), state that the role of job satisfaction is one of the factors that can have a positive and significant impact on organizational commitment. Arshadi's (2010), research states that work motivation and job satisfaction have a positive and significant effect on employee organizational commitment. Research by Ngadiman \& Sohidin (2014), in their

Title Astiti, M. W., \& Surya, I. B. K. (2020). The role of organizational commitments in mediating the effect of work motivation and job satisfaction towards turnover intention on nurses private hospital. International Research Journal of Management, IT and Social Sciences, 8(1), 25-34. https://doi.org/10.21744/irjmis.v8n1.1101 
research, found that job satisfaction has a positive and significant effect on organizational commitment. Chen (2006), also found that job satisfaction has a positive and significant effect on organizational commitment.

\section{The role of organizational commitment in mediating the effect of work motivation and turnover intention}

The results of the analysis show that organizational commitment can negatively and significantly mediate the relationship between work motivation and turnover intention. However, in this study, organizational commitment acts as a partial mediation. Based on these results, to reduce employee turnover intention, the hospital must increase the work motivation of its employees, by increasing work motivation as well as increasing employee organizational commitment. The results of this study support the study of Fernet et al. (2017), motivation negatively affects turnover through commitment mediation. Gardner et al. (2011) stated that there is a negative effect of affective organizational commitment which mediates the relationship between motivation and turnover. According to Galletta et al. (2011), work commitment fully mediates the relationship between intrinsic work motivation and intention to move. According to Kim (2018), work motivation negatively and significantly affects the intention to move. Research by Park \& Jung (2015), stated that organizational commitment could act as a mediator that affects turnover intention.

\section{The role of organizational commitment in mediating the effect of job satisfaction and turnover intention}

The results of the analysis show that organizational commitment can negatively and significantly mediate the relationship between job satisfaction and turnover intention. However, in this study, organizational commitment acts as a partial mediation. Based on these results, to reduce employee turnover intention, the hospital must increase employee job satisfaction, by increasing job satisfaction as well as increasing employee organizational commitment. The results of this study support the study of Youcef et al. (2016), the function of organizational commitment as an intermediary for the variables between job satisfaction and turnover intention serves as a mediator or intermediary variable that affects job satisfaction to move to produce a negative and significant effect. According to Mathieu et al. (2016), job satisfaction and organizational commitment can influence intention to leave. Organizational commitment has a direct effect on explaining turnover intention. According to Risma et al. (2018), job satisfaction has a significant effect on organizational commitment. Organizational commitment has a significant effect on turnover intention. Indrayanti \& Riana (2016), shows that job satisfaction has a negative and significant effect on turnover intention through mediating organizational commitment. The organizational commitment negatively and significantly mediates the relationship between job satisfaction and turnover intention.

\section{Research limitations}

There are several limitations in the process of implementing and completing this research which can be used as a reference for perfecting further research. Some of these limitations include this study relies on the results of a questionnaire with a large number of indicators used, this has the potential to provide saturation and confuse respondents in filling in so that it can affect the answers that are considered by certain values that are acceptable in their environment, so this can distort the average value for each variable. The scope of the research is still limited, namely only in two hospitals located in South Kuta, considering that there are still several private hospitals in the South Kuta area but in the current situation and conditions of the COVID 19 pandemic, researchers cannot access the hospital. With the occurrence of the national problem of the COVID 19 pandemic when researchers researched hospitals which resulted in uncertain dynamics of change in each period, of course, this had an impact on the answers given by respondents due to the reduction or termination of work relations (layoffs) carried out by home management sick so that it can affect respondents' answers and research results. This is supported by research by Hamauche (2020), which states that the Covid 19 pandemic can cause sharp shocks to economies and communities around the world (MacIntyrea; Shigemura et al., In Hamauche, 2020). This situation can hurt business sustainability and individual employment. This has triggered leave and layoffs (World Economic Forum, in Hamauche, 2020) so that in this case employees will take care of themselves and try to maintain their job positions. 


\section{Conclusion}

Based on the analysis and discussion, as a conclusion and research results, the following results are obtained: Work motivation hurts turnover intention. The lower the work motivation of the nursing staff, the higher the nurse's intention to leave the hospital. Job satisfaction hurts turnover intention. The lower the job satisfaction of the nursing staff, the higher the nurse's intention to leave the hospital. Organizational commitment hurts turnover intention. The lower the organizational commitment of the nursing staff, the higher the intention of the nurse to leave the hospital. There is a positive and significant influence between work motivation and organizational commitment. The higher the work motivation, the higher the organizational commitment of the nursing staff to stay in the company. There is a positive and significant influence between job satisfaction and organizational commitment. This means that the higher the job satisfaction, the higher the organizational commitment of the nursing staff to stay in the company. Organizational commitment can partially mediate the effect of work motivation on turnover intention. This means that to reduce turnover intention, employee work motivation must be increased, by increasing work motivation, can also increase organizational commitment. Organizational commitment s able to mediate the effect of job satisfaction on turnover intention partially. To reduce turnover intention, employee job satisfaction must be further improved, with increased job satisfaction at the same time increasing organizational commitment.

Based on these conclusions, some suggestions can be put forward which are expected to be of benefit to the company, especially for RSU. Kasih Ibu Kedonganan and RSU. Bali Jimbaran and also for other related parties. The suggestions given include: This study has proven that organizational commitment can play a role as a mediating variable to influence the turnover intention of nurses in the hospital, so it is suggested that hospital management continue to maintain the commitment of nurses to the hospital to increase the commitment of nursing staff in the organization which will certainly reduce the desire to get out. Further researchers are advised to use or develop other variables that are thought to be capable of influencing or mediating employee turnover intention when conditions have returned to normal because it is felt that the covid 19 disasters will certainly affect the research results. The turnover intention variable that gets the highest average score is a statement or indicator about having a desire to leave the hospital if there is a better offer or opportunity, so it is recommended that hospital management pay more attention to managing its workforce by negotiating, providing greater offer from competitors to nurses who want to be retained to discourage their intention to move, especially for nursing staff who are still low graduates but have an important role for the hospital. The organizational commitment variable that gets the lowest average score is a statement or indicator about feeling easily tied to other hospitals such as being tied to the hospital where they work now, so it is recommended that hospital management pay attention to factors that can support employee loyalty so that stay in the hospital such as offering more compensation than competitors, the existence of a remuneration program, training, awarding, and periodic employee gathering events that function to build intimacy between units or divisions, it is hoped that this offer can make nurses feel bound and proud to be a part of it from the hospital. The job satisfaction variable that gets the lowest average value of statements or indicators about being satisfied with the comfort found in this hospital, so that hospital management needs to pay attention to the working conditions of nurses in the field, both in terms of work support facilities and their workload. receive when treating patients. Also, statements or indicators regarding salaries that are following workloads get the second-lowest score, so it is recommended that hospital management pay more attention to the current salary system, it is hoped that these changes can increase the job satisfaction of nurses. The work motivation variable that gets the lowest average value of statements or indicators about working as a nurse allows me to make much money, so it is recommended that hospital management pay attention to the management of the salary given which can be adjusted according to the length of service, workload, or performance of each worker foster morale because there are rewards by the work done.

\section{Conflict of interest statement}

The authors declared that they have no competing interests.

\section{Statement of authorship}

The authors have a responsibility for the conception and design of the study. The authors have approved the final article.

\section{Acknowledgments}

We are grateful to two anonymous reviewers for their valuable comments on the earlier version of this paper.

Title Astiti, M. W., \& Surya, I. B. K. (2020). The role of organizational commitments in mediating the effect of work motivation and job satisfaction towards turnover intention on nurses private hospital. International Research Journal of Management, IT and Social Sciences, 8(1), 25-34. https://doi.org/10.21744/irjmis.v8n1.1101 


\section{References}

Ahn, M. K., Lee, M. H., Kim, H. K., \& Jeong, S. H. (2015). Job satisfaction, organizational commitment and turnover intention among male nurses. Journal of Korean academy of nursing administration, 21(2), $203-211$.

Al-Emran, M., \& Salloum, S. A. (2017). Students' attitudes towards the use of mobile technologies in eEvaluation. International Journal of Interactive Mobile Technologies (IJIM), 11(5), 195-202.

Alfitri, A., Ngadiman, N., \& Sohidin, S. (2013). Penerapan Standar Akuntansi Keuangan Entitas Tanpa Akuntabilitas Publik (Sak-Etap) Pada Usaha Mikro Kecil Menengah (Umkm) Perajin Mebel Desa Gondangsari Kecamatan Juwiring Kabupaten Klaten. Jurnal Pendidikan Ekonomi Universitas Sebelas Maret, 2(2), 13577.

Ananto, S., Rahyuda, I. K., \& Priartrini, P. S. (2016). Pengaruh Motivasi Terhadap kepuasan Kerja dan Intensi Keluar Pada Asisten Kursus Metode Kumon di Bali dan Lombok. E-Jurnal Ekonomi dan Bisnis, 5(9), 3057-3086.

Arshadi, N. (2010). Basic need satisfaction, work motivation, and job performance in an industrial company in Iran. Procedia-Social and Behavioral Sciences, 5, 1267-1272. https://doi.org/10.1016/j.sbspro.2010.07.273

Basariya, S. R., \& Ahmed, R. R. (2019). The Influence of 'Adventure Tourism Activities' in promoting tourism business in mountain stations. Journal of Hospitality and Tourism Management, 8(2), 1-10.

Bonenberger, M., Aikins, M., Akweongo, P., \& Wyss, K. (2014). The effects of health worker motivation and job satisfaction on turnover intention in Ghana: a cross-sectional study. Human resources for health, $12(1), 43$.

Can, A., \& Yasri, Y. (2016). Pengaruh Motivasi Kerja, Kepuasan Kerja Dan Komitmen Organisasi Terhadap Kinerja Karyawan Pada Bank Nagari. Jurnal Riset Manajemen Bisnis dan Publik, 4(1).

Chen, C. F. (2006). Job satisfaction, organizational commitment, and flight attendants' turnover intentions: A note. Journal of Air Transport Management, 12(5), 274-276. https://doi.org/10.1016/j.jairtraman.2006.05.001

Eddy, M. S., Agusta, Leonando. 2013. Pengaruh Pelatihan Dan Motivasi Kerja Terhadap Kinerja Karyawan Cv Haragon Surabaya. Agpra, Vol.1, No.3. Pp 7-14.

Fernet, C., Trépanier, S. G., Demers, M., \& Austin, S. (2017). Motivational pathways of occupational and organizational turnover intention among newly registered nurses in Canada. Nursing outlook, 65(4), 444-454. https://doi.org/10.1016/j.outlook.2017.05.008

Galletta, M., Portoghese, I., \& Battistelli, A. (2011). Intrinsic motivation, job autonomy and turnover intention in the Italian healthcare: The mediating role of affective commitment.

Gardner, T. M., Wright, P. M., \& Moynihan, L. M. (2011). The impact of motivation, empowerment, and skillenhancing practices on aggregate voluntary turnover: The mediating effect of collective affective commitment. Personnel psychology, 64(2), 315-350.

Hamouche, S. (2020). COVID-19 and employees' mental health: stressors, moderators and agenda for organizational actions. Emerald Open Research, 2(15), 15.

Han, G., Liang, C. Z., Chung, T. S., Weber, M., Staudt, C., \& Maletzko, C. (2016). Combination of forward osmosis (FO) process with coagulation/flocculation (CF) for potential treatment of textile wastewater. Water research, 91, 361-370. https://doi.org/10.1016/j.watres.2016.01.031

Harnoto, E. (2002). Perbandingan Analisa Biaya Jalan Lingkar UII Terpadu Antara Perkerasan Flexibel dan Perkerasan Paving Block.

Imran, M., Anwar, Z., Irshad, M., Javid, A., Hussain, A., \& Ali, S. (2017). Optimization of cellulase production from a novel strain of Aspergillus tubingensis IMMIS2 through response surface methodology. Biocatalysis and Agricultural Biotechnology, 12, 191-198. https://doi.org/10.1016/j.bcab.2017.10.005

Imran, R., Allil, K., \& Mahmoud, A. B. (2017). Teacher's turnover intentions. International Journal of Educational Management.

Indrayanti, D. P., \& Riana, I. G. (2016). Pengaruh Kepuasan Kerja Terhadap Turnover Intention Melalui Mediasi Komitmen Organisasional Pada PT. Ciomas Adisatwa Di Denpasar. E-Jurnal Manajemen Universitas Udayana, 5(5).

Ismail, A., \& Razak, M. R. A. (2016). EFFECT OF JOB SATISFACTION ON ORGANIZATIONAL COMMITMENT. Management \& Marketing Journal, 14(1).

Kim, H., Kang, D. S., Lee, S. W., \& McLean, G. (2016). Career commitment as a mediator between organizationrelated variables and motivation for training and turnover intentions. Journal of Career Development, 43(2), 130144.

Kim, J. (2018). The contrary effects of intrinsic and extrinsic motivations on burnout and turnover intention in the public sector. International journal of manpower. 
Koesmono, H. T. (2005). Pengaruh budaya organisasi terhadap motivasi dan kepuasan kerja serta kinerja karyawan pada sub sektor industri pengolahan kayu skala menengah di Jawa Timur. Jurnal manajemen dan kewirausahaan, 7(2), 171-188.

Lam, C. F., \& Gurland, S. T. (2008). Self-determined work motivation predicts job outcomes, but what predicts selfdetermined work motivation?. Journal of research in personality, 42(4), 1109-1115. https://doi.org/10.1016/j.jrp.2008.02.002

Li, X., Li, Z., Wang, E., Liang, Y., Li, B., Chen, P., \& Liu, Y. (2018). Pattern recognition of mine microseismic and blasting events based on wave fractal features. Fractals, 26(03), 1850029.

Liu, H. L., \& Lo, V. H. (2018). An integrated model of workload, autonomy, burnout, job satisfaction, and turnover intention among Taiwanese reporters. Asian Journal of Communication, 28(2), 153-169.

Lu, K. Y., Lin, P. L., Wu, C. M., Hsieh, Y. L., \& Chang, Y. Y. (2002). The relationships among turnover intentions, professional commitment, and job satisfaction of hospital nurses. Journal of Professional Nursing, 18(4), $214-219$. https://doi.org/10.1053/jpnu.2002.127573

Makary, M. A., Sexton, J. B., Freischlag, J. A., Holzmueller, C. G., Millman, E. A., Rowen, L., \& Pronovost, P. J. (2006). Operating room teamwork among physicians and nurses: teamwork in the eye of the beholder. Journal of the American College of Surgeons, 202(5), 746-752. https://doi.org/10.1016/j.jamcollsurg.2006.01.017

Martoyo, S. (2000). Manajemen Sumber Daya Manusia Edisi 4. Yogyakarta: BPFE.

Mathieu, C., Fabi, B., Lacoursière, R., \& Raymond, L. (2016). The role of supervisory behavior, job satisfaction and organizational commitment on employee turnover. Journal of Management and Organization, $22(1), 113$.

Mobley, W. H. (2011). Pergantian Karyawan: Sebab-Akibat dan Pengendaliannya, Cet. 1: PT. Gramedia: PPM dan Bisnis, 2030.

Mosadeghrad, A. M. (2013). Occupational stress and turnover intention: implications for nursing management. International journal of health policy and management, 1(2), 169.

Mustafa, G., \& Ali, N. (2019). Rewards, autonomous motivation and turnover intention: Results from a non-Western cultural context. Cogent Business \& Management, 6(1), 1676090.

Nawawi, M. T. (2015). Pengaruh Kepuasan Kerja, Dan Motivasi Kerja Terhadap Kinerja Karyawan Dengan Komitmen Organisasional Sebagai Variabel Intervening (Studi Karyawan Outsourcing PT. J Yang Ditempatkan Di Kampus II Untar Jakarta). 3(1), 129-143.

Nerissa, A. C. (2015). Pengaruh Komitmen Continuance Dan Work Engagement Terhadap Job Embeddedness Karyawan Pt. Matahari Department Store, Tbk Malioboro Mall - Yogyakarta.

Nuansa, R., Thatok, A., \& Siti, N. (2018). The role of organizational commitment mediation on the effect of personorganization fit and job satisfaction to turnover intention. Russian Journal of Agricultural and Socio-Economic Sciences, 74(2).

Paat, G., Tewal, B., \& Jan, A. B. H. (2017). Pengaruh Komitmen Organisasi, Kepuasan Kerja, Stres Kerja terhadap Turnover Intention Karyawan Kantor Pusat PT. Bank Sulutgo Manado. Jurnal EMBA: Jurnal Riset Ekonomi, Manajemen, Bisnis dan Akuntansi, 5(3).

Park, I. J., \& Jung, H. (2015). Relationships among future time perspective, career and organizational commitment, occupational self-efficacy, and turnover intention. Social Behavior and Personality: an international journal, 43(9), 1547-1561.

Pawesti, R., \& Wikansari, R. (2016). Pengaruh kepuasan kerja terhadap intensi turnover karyawan di Indonesia. Jurnal Ecopsy, 3(2).

Puspasari, A. (2013). Emotional Intelligent Parenting \& Relationships. Elex Media Komputindo.

Ramlall, S. (2004). A review of employee motivation theories and their implications for employee retention within organizations. Journal of American academy of business, 5(1/2), 52-63.

Raziq, A., \& Maulabakhsh, R. (2015). Impact of working environment on job satisfaction. Procedia Economics and Finance, 23, 717-725. https://doi.org/10.1016/S2212-5671(15)00524-9

Ridlo, I. A. (2012). Turnover karyawan "Kajian literatur". Surabaya: Public Health Movement.

Salleh, S. M., Zahari, A. S. M., Said, N. S. M., Ali, S. R. O. (2016). The Influence of Work Motivation on Organizational Commitment in the Workplace.J. Appl. Environ. Biol. Sci, 6(5), 139-143.

Schwepker Jr, C. H. (2001). Ethical climate's relationship to job satisfaction, organizational commitment, and turnover intention in the salesforce. Journal of business research, 54(1), 39-52. https://doi.org/10.1016/S01482963(00)00125-9

Sy, T., Tram, S., \& O'hara, L. A. (2006). Relation of employee and manager emotional intelligence to job satisfaction and performance. Journal of vocational behavior, 68(3), 461-473. https://doi.org/10.1016/j.jvb.2005.10.003

Title Astiti, M. W., \& Surya, I. B. K. (2020). The role of organizational commitments in mediating the effect of work motivation and job satisfaction towards turnover intention on nurses private hospital. International Research Journal of Management, IT and Social Sciences, 8(1), 25-34. https://doi.org/10.21744/irjmis.v8n1.1101 
Takase, M. (2010). A concept analysis of turnover intention: Implications for nursing management. Collegian, 17(1), 3-12. https://doi.org/10.1016/j.colegn.2009.05.001

Tharikh, S. M., Ying, C. Y., \& Saad, Z. M. (2016). Managing job attitudes: The roles of job satisfaction and organizational commitment on organizational citizenship behaviors. Procedia Economics and Finance, 35, 604611. https://doi.org/10.1016/S2212-5671(16)00074-5

Wahyuni, A. S., Zaika, Y., \& Anwar, R. (2015). Analisis faktor-faktor yang mempengaruhi turnover intention (keinginan berpindah) karyawan pada perusahan jasa konstruksi. Rekayasa Sipil, 8(2), 89-95.

Wang, E., Hu, H., Mao, S., \& Liu, H. (2019). Intrinsic motivation and turnover intention among geriatric nurses employed in nursing homes: the roles of job burnout and pay satisfaction. Contemporary nurse, 55(2-3), 195-210.

Widiawati, F., Amboningtyas, D., Rakanita, A. M., \& Warso, M. M. (2017). Pengaruh Beban Kerja, Stress Kerja dan Motivasi Kerja Terhadap Turnover Intention Karyawan PT Geogiven Visi Mandiri Semarang. Journal of Management, 3(3).

Widjaja, A. W. (2006). Administrasi kepegawaian. Jakarta: Rajawali.

Widyadmono, V. M. (2015). Pengaruh Kepuasan Kerja dan Komitmen Organisasi terhadap Turnover Intention (Studi pada Accounting Staff Perusahaan Swasta di DIY). Jurnal Manajemen Indonesia, 15(2), 157-168.

Youcef, S., Ahmed, S. S., \& Ahmed, B. (2016). The impact of job satisfaction on turnover intention by the existence of organizational commitment, and intent to stay as intermediates variables using approach PLS in sample worker department of transport Saida. Management, 6(6), 198-202. 